\title{
Spinning Solitude: Coronavirus and the Philosopher
}

\author{
Sanjit Chakraborty ${ }^{1}$
}

Accepted: 8 May 2021 / Published online: 28 July 2021

(c) The Author(s), under exclusive licence to Springer Nature B.V. 2021, corrected publication 2021

\begin{abstract}
This fictionalized script (fictional dialogue between Coronavirus and the Philosopher) traces the contours of the conversation that seeks to fathom the crisis unleashed by the outbreak and global spread of the coronavirus (COVID-19 pandemic) and the ensuing anxieties created in our current social living. The scenario of deepened isolation of the self from the other (social distancing and 'stay-at-home' or various lockdowns) is considered, and it is proposed (by the philosopher, I presume) that isolation, while an unavoidable requirement, does not mean it is some mental lassitude but rather may be seen as an enthusiastic concern toward recovering physical and mental wellbeing of the larger communities concerned to control the possible avenues of transmission of the contagion. The conversation meanders around the issue of quarantine, its attraction or otherwise, and who benefits from this restriction, its effects on one's mental constitution, etc. Philosophers have been known to isolate themselves in other contexts and situations (Yãjñavalkya and the Buddha withdrawing to the forest; the Jain mendicants crossing "the ford"; the Stoics withdrawing from society, Nietzsche's retreating regularly to the sanatorium; Heidegger to the Black Forest; Kant's unsocial sociability and Wittgenstein living lonesome lives, etc.) give us a taste of what is to come in the dialogue to resist the calamity of the coronavirus and its grim effects that engulf the entire humanity.
\end{abstract}

Keywords Coronavirus · Philosopher - Solitude $\cdot$ Unsociable sociability · Egoistic suicide $\cdot$ Vedās · Yājñavalkya $\cdot$ Manichaeism $\cdot$ Cosmopolitanism Incommensurability of cultures $\cdot$ Humanity $\cdot$ John Keats $\cdot$ Durkheim

COVID-19/Coronavirus (henceforth Corona): How are you feeling, philosopher, in your self-isolation?

Philosopher: Nothing unusual; we (philosophers) have had a long tradition of keeping ourselves in solitude for better mental health and clarity. And occasionally,

Sanjit Chakraborty

sc013@iiserkol.ac.in; apanditsanjit@gmail.com

1 Teaching Faculty, Indian Institute of Science Education and Research Kolkata, Mohanpur, West Bengal 741246, India 
we practice the same. I prefer feeling alone, even in crowds, and that helps me in constructing reflective thoughts. Let me tell you that solitude and internal reflection do not result in solipsism.

Corona: Well, but as far as I know, earlier, you never maintained social distance with your friends or other people during your conversations or meetings.

Philosopher: Be that as it may, you would be surprised to learn how often philosophers have praised solitude and kept themselves in quarantine. Pythagoras, the prominent Greek intellectual, had almost a cult practice in solitude away from social life. Look at our ancient Stoics (Seneca, or Marcus) or Montaigne's idea of 'true solitude', you will find an indispensable resource of literary content on solitude. This also holds true in the case of romantic poets and philosophers like Rousseau, Kant, Wordsworth, and Keats. In a sonnet, John Keats writes:

O Solitude! if I must with thee dwell,

Let it not be among the jumbled heap

Of murky buildings; climb with me the steep,-

Nature's observatory-whence the dell,

Its flowery slopes, its river's crystal swell

Is my soul's pleasure; and it sure must be

Almost the highest bliss of human-kind,

When to thy haunts two kindred spirits flee (Keats, 1855, 341-342).

Corona: I know, old Wordsworth would be another remarkable example of Nature lovers like Rabindranath Tagore and John Keats. He loved solitary wandering in Nature since he believed in Nature's moral and spiritual influences on humans' minds, but sardonically, Wordsworth had trained his solitary mind to engage with some despondent isolated old villagers because of his amicable personality.

Observably, in the Symposium there is a striking scene where Socrates attends a party and opts to stand outside in a chilling weather, while his male suitor and pupil Alcibiades, waxes eloquent about the virtues of love and how he is besotted with Socrates. Despite it being a salacious content, the aforementioned discourse has been a debatable issue for commentators.

Philosopher: But, there may be some situations in life when one is in a party, or a meeting and one does not prefer to share one's thoughts with the people partaking in such events. One does not wish to interact socially. In such situations, one may not be interested in taking part in the communicative actions of the Habermasian sense.

As we know, in his early life, Sri Aurobindo appreciated verbal interactions with his followers. However, he changed his mind when he realized that no individual pattern of self-isolation could be evolved when one's mind is in the process of interacting with a large number of people. Later, Sri Aurobindo kept himself in solitude for many years in a small room in Pondicherry to cognize the sheer delight of life-divine. He spoke with his fellows and outsiders only twice a year. In contemporary times, Ramana Maharshi and Sri Ramakrishna are most likely better examples who fulfilled their need for solitude and solitary contemplation through the stage of samnnyāsa. 
Having said this, we must, however, acknowledge the thoughts of the Sufi mystical poet and an eminent writer Ibn Arabi who in his masterpiece Journey to the Lord of Power (Arabi, 1981) considers solitude as the first requirement of our spiritual path, and a necessary disposition. He says that it seems essential for seekers to remain isolated from people. He further states that a seeker's inclination for refraining from human associations looks unavoidable, since as much as one could live apart from creation and people is the necessary condition of one's nearness to God, externally and inwardly.

Modern western philosophers like Heidegger, Nietzsche, Wittgenstein, Iris Murdoch, and Bernard Williams opted for solitude with deliberate intent. They kept themselves alone with their minds and mental representations about the objective world. At an invited party, Wittgenstein spent the entire time watching a fish tank at the doorway of the hosts' residence. He then suddenly left and only returned later to ask the host: 'What thinks the fish?' This event is a pretty good reflection on the solitariness of one's thoughts.

I will pursue a little further the line of thought that analytic philosophers developed. At one stage, it seems to me that analytic philosophy is central to philosophical discussion. In the philosophy of mind and language, it seems pretty clear that some contents occur in the brain (internal organ). However, it is not uncommon for biological systems to take a cue from external inputs in order to develop one's physical immunity and language acquisition. The mental states are by nature representational, while the occurrences of the mind are intrinsically characterized (narrow content) to catch mechanisms such as feelings, images, and sensations in various situations. Therefore, introspective evidence is inadequate to nullify the content of the mind. Whenever we have anything intelligible as mental representation, we have something recognizable as mental content. The concept of meaning sounds relatable since one might think of meaning as a part of what determines the content of one's thought. However, as far I know, the quest for the 'meaning without language' hypothesis could be feasible in terms of mental representations that are non-linguistic by nature (Chakraborty, 2020, 219-220). We may take an example of mental imagery here. In fact, thoughts as conceptual contents turn towards the mentalese programs of the brain, but the expressions of thoughts causally hook to language and society.

Corona: I hope you realize that COVID-19 has created challenging times for the world where it looks decisively perilous to stay focused since the eruption of the virus is relentless. Its RNA genomes are contaminating the epithelial cells of the respiratory tract as well as the living carrier's cell-ribosome. After all, you people are social animals fond of gatherings and meeting up with each other. How long would you people be able to incarcerate yourselves in your small homes?

Philosopher: For your information, I prefer to make mention of Kant's idea of the principle of solitude that he exemplifies as "unsociable sociability" (Wood, 1991, 341). This hypothesis is not in any way a type of misanthropy, but a virtuous solitude in which a solitary people deliberately prefer to isolate (not to hate humanity) them from the moral turpitude of people. This is done to uphold moral principles and a benevolent philanthropic outlook. In his Nicomachean Ethics, Aristotle depicts human beings as social and political animals. Later in the closing part of the 
book, he claims that absolute happiness is attainable only through the proper implementation of reasoning that brings the state of solitude to an agent's mind.

In the 1960s, under the impact of Allen Ginsberg and Gary Snyder and the sweep of Buddhism, Hindu guru-following, yoga, and meditation, practicing youngsters from middle-class homes retreated to the countryside. Some of these youngsters set up communes like the Kibbutz in Israel, and prior to that Tolstoy Farm and the Phoenix Settlement, established by Gandhi in South Africa. Gandhi also set up ashrams (Sabarmati Ashram and Sevagram Ashram) in India. Numerous Tibetan and Zen monasteries sprang up - even in the middle of the cities like New York and San Francisco - Vedanta ashrams in Hollywood and Sonoma Valley, and Soto-Zen farms in Green Gulch, all in California, not to mention ashrams and retreat centers established by Swami-monks sent by Swami Sivananda and Vivekananda mission in Belur, Kolkata. Autobiography of a Yogi was a great inspiration for many would-be yogis and solitary yoga practitioners, as were the celebrated movement and Integral Cultural Fellowships set up by followers of Sri Aurobindo in North America. Besides, Tibetan Buddhism attracted students who took initiation and became monks, nuns, Rinpoches, and Geshes in Dharmasala or Bodhgaya or Tibet and returned to teach the art of Zen life-of-solitude in the West. ${ }^{1}$

Corona: My dear philosopher! I hope you remember that Durkheim once cautioned about the concept of "egoistic suicide," a type of psychological disturbance formed because of the inability or unwillingness to live or interact with the people in the society. Many people (especially old fellows) are already suffering from mental depression. Besides, the children whom you have confined at home, are presently showing their self-destructive behaviors and dissatisfaction as well.

Philosopher: Well, here we need to remember the valuable words once uttered by sage Yājñavalkya to his beloved wife Maitreȳ̄ when he was going into solitude to the forest. He says that the term 'love' or affection turns out to be a misnomer once we explore its essence. No one loves anything for its own sake; actually, the things become desired to the individual that is attributable to the Self (âtmanastu kāmāya sarvam priyam bhavati). Here the subject consciousness (vișaȳ cetanā) collides with the other consciousness (vișayā cetanā) for its own interest. So, it looks quite promising when people for their own wellbeing or interest, are keeping themselves in solitude or quarantine at home. The deliverance of the Self is achieved not through confinement within a finite boundary. We must surpass the bondage of the finitude to realize the infinity. The Vedic tradition appreciates the one who has closed their external eyes for expanding their inward perception.

In these prevalent weird moments, the stage of home quarantine would be a good practice for all of us. It would also provide a pleasant occasion for the parents to expend considerable time with their children and thus cultivating more love and understanding within their families.

Now let me get back to the question of the 'psychological disturbance' in the period of lockdown and solitude. I truly favor the psychological account of

\footnotetext{
${ }^{1}$ I extend my sincere thanks to Purushottama Bilimoria for bringing these wonderful points to my attention.
} 
Manichaeism here. We are an upshot of the battle of two apparently diverse but literally intertwined directions - life and death. Our psychological happiness in a wider span reflects a startling obsession with managing life in such a way as to enhance our resilience, even though the opposing force, namely death, enters as a dread into our psychological sphere. The duo of life and death cultivate the self-constructive and self-destructive passions concurrently in our minds. We are able to express our creativity in the self-constructive mode, while mental depressions abide the self-destructive conduct. This gyrating resistance constitutes the essence of life that Sigmund Freud refers to as '...battle of the giants that our nurse-maids try to appease with their lullaby about Heaven' (Freud, 1974, 122).

Corona: Be more practical, philosopher! How would you contend with the intense upsurge of the virus? Eventually, in this draconian lockdown, it will dampen your spirits psychologically and physically. Anxiety and panic and along with the proliferation of fake news in social media would not help you all in building resilience and nurturing positive thoughts.

Philosopher: This situation is not to be overlooked through merely the stage of disparage (floccinaucinihilipilification). When self-isolation looks inevitable, individual separation from community gathering is required. It does not mean a kind of indolence of mental dejection, rather, it is an energetic quest for recovering the mental health of the quarantined person. It traces the contours of the conversation that seeks to understand the crisis unleashed by the outbreak and global spread of the COVID-19 pandemic and the ensuing anxieties created in our present social living. The scenario of self and other-isolation (social distancing and 'stay-at-home' or various lockdowns) is considered, and it is proposed (by the philosopher, I presume) that isolation, while an unavoidable requirement, does not mean it is some kind of mental lassitude but rather may be seen as an enthusiastic concern toward recovering physical and mental wellbeing of the larger communities concerned in order to control the possible avenues of transmission of the contagion.

Corona: If I am not wrong, you intend to embrace Beyond good and evil and Nietzsche's exegesis theorem from suicidal nihilism as helpful means for human beings during these testing times. I am assuring you that even as a theory, it sounds too tedious for the people who are in a vulnerable position of losing their jobs, health, academic stability, and love. One has to opt either for social networking or social distancing. Both choices create circumstances for a crisis.

Philosopher: This endemic disaster is a module of the ethical outcome of human suffering caused by negligent human actions causing great harm to the environment and pushing it to the gulf of oblivion. This pandemic-driven suffering looks to be a consequence of our damaging the environment. The endangered species we have damaged, and we ourselves have joined them!

Most likely, in the third century AD, the celebrated dictum - 'the citizen of the world' got a new stand in the thoughts of the western stoic-cynic philosopher Diogenes Laertius. The present idea of cosmopolitanism came from the Greek word kosmopolitês, where one is not only a moral member of the local community, but also an inseparable member of the world. In a dynamic form, the thesis of 
cosmopolitanism has been hailed in the Vedic culture and Upanișadic hymns, where the sages of the Vedās perceive:

\section{स नो बन्धुरजनतिता स वंधिता धामाना वेद भुवंनाना विश्वां \\ Sa no bandhưrjanitā sa vidhātā \\ Dhamāni veda bhuvanāni viśva. (Yajurveda, 32-10)}

The meaning of the hymns glossily signifies that He is the creator, friend, and controller of us. He knows the entire universe and understands all created beings.

We need to understand that the universe does not depend exclusively on human truth. The truth (the conception of harmony) that enlivens humans and the universe or living beings with Nature is not only metaphysically but ethically reliant on the zenith of creation. Rabindranath Tagore once wonderfully wrote, 'What the intellect is in the world of Nature, our will is in the moral world' (Tagore, 1985, 82).

We revitalize the principle of "incommensurability of cultures," in line with Charles Taylor's sense of 'accord equal respect to actually evolved cultures' (Taylor, 1994, 42). Besides, the context of the abiding expansion of universal-realization of humanity needs to be linked with the dimensions of moral values, care, and philosophizing life - an art of life with numerous ecosystems. We know that a vaccine seems to be the only solution for the pandemic problem, but this seemingly viable solution might not become practicable without the pharmaceutical companies first calculating their turnover and raking in huge profits in the procedure. While speaking of a way to prevail over any detrimental effect, we need to think about the explored aperture of the welfare of humanity that is a stratified ascension towards reminiscent social livings.

Acknowledgements I would like to acknowledge the trenchant comments of Purushottama Bilimoria and anonymous reviewers that helped me in constructing the earlier draft of this fictionalized conversation between coronavirus versus the philosopher. Thanks as well to Simon Blackburn (University of Cambridge) and Swami Medhananda (Ramakrishna Mission, Belur Math) for their help and encouragement.

\section{References}

Arabi, I. (1981). Journey to the Lord of Power: A sufi manual on retreat (trans: Rabia Terri Harris). Inner Traditions International.

Chakraborty, S. (2020). The labyrinth of mind and world: Beyond internalism-externalism. Routledge.

Freud, S. (1974). J. Strachey (Ed.), Standard edition of the complete psychological works of Sigmund Freud. Hogarth Press.

Keats, J. (1855). R Milnes (Ed.), The poetical works of John Keats. E.H Butler \& Co.

Tagore, R. (1985). Personality. Macmillian.

Taylor, C. (1994). The politics of recognition. In A Gutmann (Ed.), Multiculturalism (1st ed., pp. 25-75). Princeton University Press.

Wood, A. (1991). Unsociable sociability: The anthropological basis of Kantian ethics. Philosophical Topics, 19, (1), 325-351.

Publisher's Note Springer Nature remains neutral with regard to jurisdictional claims in published maps and institutional affiliations. 